\title{
Four thousand years of plant exploitation in the Chad Basin of northeast Nigeria I: The archaeobotany of Kursakata
}

\author{
Marlies Klee', Barbara Zach $^{2}$ and Katharina Neumann² \\ ${ }^{1}$ Universitaet Basel, Botanisches Institut, Schoenbeinstrasse 6, CH-4056 Basel, Switzerland \\ ${ }^{2}$ Seminar für Vor- und Frühgeschichte, Archäologie und Archäobotanik Afrikas, Johann Wolfgang Goethe-Universität Frankfurt, \\ Robert-Mayer-Str. 1, D-60325 Frankfurt, Germany
}

Received January 13, 2000 / Accepted June 19, 2000

\begin{abstract}
This paper discusses archaeobotanical remains from the settlement mound of Kursakata, Nigeria, comprising both charred and uncharred seeds and fruits as well as charcoal. In addition, impressions of plant tempering material in potsherds were analysed. The late Stone Age and Iron Age sequence at Kursakata is dated from 1000 cal. B.C. to cal. A.D. 100. Domesticated Pennisetum (pearl millet), wild Paniceae and wild rice are the most common taxa. Kernels from tree fruits were regularly found including large numbers of Vitex simplicifolia - a tree which is absent from the area today. A distinct change in plant spectra can be observed between the late Stone Age and the Iron Age. Although domesticated pearl millet was already known at the beginning of the settlement sequence of Kursakata, it only gained greater economic importance during the Iron Age. Besides farming, pastoralism and fishing, gathering of wild plants always played a major role in the subsistence strategy of the inhabitants of Kursakata. The charcoal results show that firewood was mainly collected from woodlands on the clay plains, which must have been more diverse than today. The end of the late Stone Age in the Chad Basin was presumably accompanied by the onset of drier environmental conditions from ca. $800 \mathrm{cal}$. B.C. onwards.
\end{abstract}

Key words: Prehistoric West Africa - Domesticated Pennisetum - Wild cereals - Charcoal - Palaeoecology

\section{Introduction}

Kursakata is a settlement mound in the Chad Basin of northeast Nigeria, situated at the northern edge of an extensive flat clay plain (firki). The Nigerian Chad Basin is one of the main study areas of a Joint Research Project of the Universities of Frankfurt, Germany and Maiduguri, Nigeria. Archaeological and archaeobotanical overviews are given by Breunig et al. (1996), Breunig and Neumann (1999), Gronenborn (1996, 1998), Gronenborn et al.

Correspondence to: M. Klee, email: Marlies.Klee@unibas.ch
(1996), Klee and Zach (1999) and Neumann (1999a). Investigations have concentrated on two ecologically different areas (Fig. 1), first the Chad Lagoonal Complex (or firki clay plains) and secondly the Bama Deltaic Complex (Aitchison et al. 1972). In the sixties, the firki were the object of intensive archaeological investigations conducted by Connah $(1976,1981)$. In 1965, Connah excavated a test trench at Kursakata down to a depth of $6.40 \mathrm{~m}$ (Connah 1981). In 1994 we revisited the site mainly in order to obtain additional archaeobotanical and archaeozoological data.

The Chad Basin plays an important role in theoretical considerations of early African agriculture. Harlan (1971) included the Chad Basin in his hypothetical domestication area of several indigenous African crops, such as Pennisetum glaucum (pearl millet), Sorghum bicolor and Oryza glaberrima (African rice). However, this hypothesis was mainly based on the modern distribution of the cultigens' wild ancestors and not on archaeobotanical data, which in general are very sparse for the whole African continent. Our investigations at Kursakata are the first comprehensive archaeobotanical study in the Chad Basin, and their aims are as follows: first to test Harlan's hypothesis, secondly to provide information on subsistence strat-

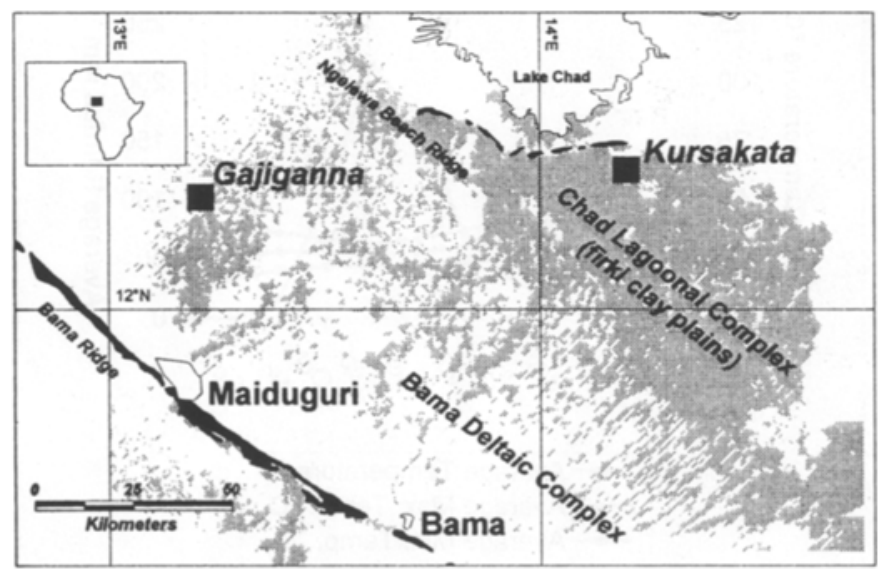

Fig. 1: The study area: NE Nigeria, the Chad Basin southwest of Lake Chad, clay plains are marked in grey, sandy areas in white 
egies and to determine when agriculture started in the region and thirdly to contribute towards a reconstruction of the palaeoenvironment and palaeoclimate.

This article is the first in a series of forthcoming publications which will present archaeobotanical results from several archaeological sites in the Nigerian Chad Basin excavated by the joint research project.

\section{The environment}

\section{Palaeoclimate and geology}

The investigated area is located in the southwestern part of the Chad basin between Lake Chad and the Bama Ridge (Fig, 1). The Bama Ridge is a fossil beach ridge built up during the early and middle Holocene wet phase, when the lake level was about $40 \mathrm{~m}$ higher than today (Servant 1983). After 5000 B.P., Lake Chad shrank as a result of increasing aridity (Thiemeyer 1992, 1993). This aridification trend has also been recorded in pollen diagrams from the Manga grasslands $200 \mathrm{~km}$ to the west (Salzmann and Waller 1998). Following the regression of Lake Chad, the southwestern plains of the basin became accessible in the late Holocene, the Bama Deltaic Complex around 1800 B.C. and the Chad Lagoonal Complex towards the end of the second millennium B.C. (Breunig and Neumann 1999).

The sediments of the Chad lagoonal complex consist of heavy clays called firki which presumably have been deposited by the retreating lake behind the Ngelewa Beach Ridge (Thiemeyer 1997). In the dry season, cracks more than one metre deep are formed in the soils. During the rainy season, the plains are almost completely flooded, with only a few elevated dry sandy hills allowing human settlement. In this way, settlement mounds with a height of up to $8 \mathrm{~m}$ have been built up in the course of the last 3000 years. The settlement mound of Kursakata $\left(12^{\circ} 19^{\prime} 011^{\prime \prime N}\right.$, $14^{\circ} 12^{\prime} 06^{\prime \prime} \mathrm{E}$ ) is situated near the village of Ngala at the edge of the sandy Ngelewa Beach Ridge adjacent to the firki plains.

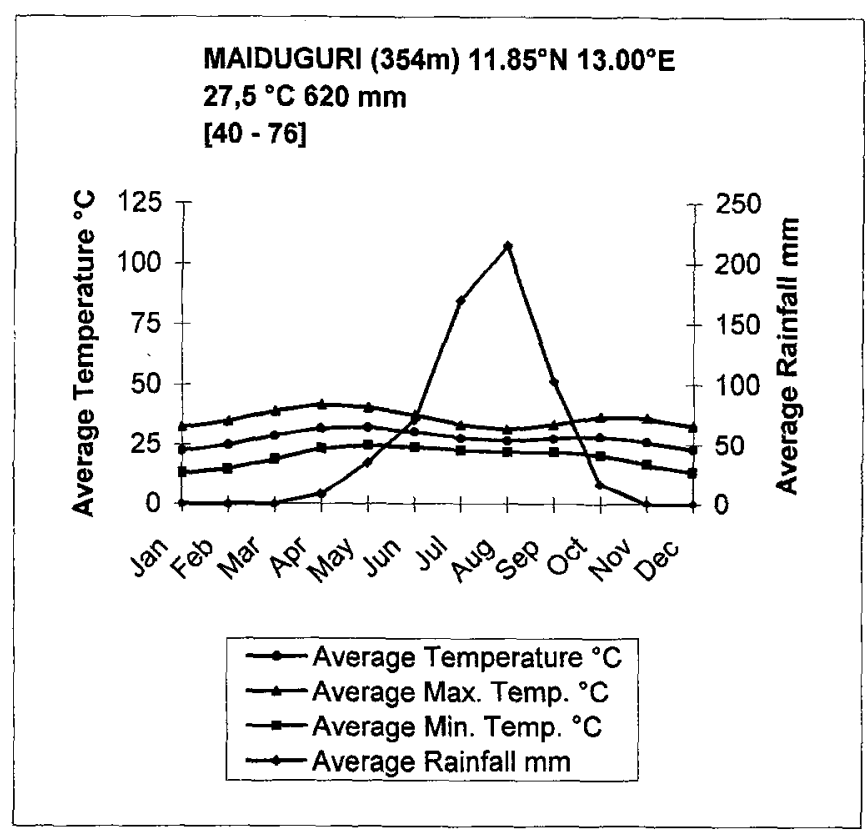

Fig. 2: Climate diagram of Maiduguri, NE Nigeria

\section{Climate}

A short rainy season in the summer (June to September) and a long dry season are typical features of the Sahelian climate. In our investigation area, the city of Maiduguri $\left(11.85^{\circ} \mathrm{N}, 13.00^{\circ} \mathrm{E}\right)$ provides the nearest meteorological station with long-term measurements of temperature and rainfall (rainfall: 1909-1985, temperature: 1916-1977; Buttle and Tuttle Ltd. 1996). The coldest month is January with a mean temperature of $22.4^{\circ} \mathrm{C}$ and the warmest May with $32.4^{\circ} \mathrm{C}$. Mean annual rainfall is $620 \mathrm{~mm}$ (Fig. 2), but seasonal and interannual variability can cause severe problems. For example, annual precipitation was $688 \mathrm{~mm}$ in 1960 , but only $396 \mathrm{~mm}$ in 1982 (Tschierschke 1998).

\section{Vegetation}

According to the vegetation maps of Keay (1959) and White (1983) and the descriptions by De Leeuw and Tuley (1972), the investigation area southwest of Lake Chad belongs to the Sudanian phytogeographical zone. However, the map of Le Houérou (1989) includes the southwestern part of the Chad basin in the Sahelo-Sudanian ecoclimatic zone, being defined by an annual rainfall of up to $600 \mathrm{~mm}$.

The vegetation shows a distinct seasonal pattern. With the exception of shallow moist depressions near Lake Chad, the herbal layer dries out during the dry season. On the firki clays most plant communities are dominated by grasses. However, patches of woody formations dominated by Acacia seyal occur.

In the vicinity of Lake Chad, where soils stay inundated for several months, the annual grass Sorghum aethiopicum forms dense stands with a maximum height of four metres (GTZ 1982, De Leeuw et al. 1972). Today, most of these stands have been replaced by the cultivation of dry-season sorghum (locally called masakwa). De Leeuw et al. (1972, p 42, community 19) describe the Sorghum aethiopicum community as the potential final phase before the land reverts to a tree savanna with Acacia spp.

Fallow communities on drier sites are characterised by Panicum laetum, Echinochloa colona, Dactyloctenium aegyptium, Setaria pallide-fusca and Pennisetum ramosum. In swamps with a high water level, Echinochloa stagnina is abundant, whereas Oryza spp., Echinochloa obtusiflora and E. pyramidalis grow on more elevated sites (De Leeuw et al. 1972).

The settlement mound of Kursakata is covered with a herbal layer dominated by Peristrophe bicalyculata, some scattered Balanites aegyptiaca trees and the weedy shrub Calotropis procera. Herbs include Acanthospermum hispidum, Achyranthes argentea, Aristida adscensionis, Aspilia helianthoides, Cassia nigricans, C. tora, Crotalaria sp., Cucumis prophetarum, Eragrostis ciliaris, E. pilosa, E. tremula, Euphorbia convolvuloides, Indigofera sp., Ipomoea vagans, Microchloa indica, Polycarpaea corymbosa, Sida alba, S. cordifolia, S. ovata, Tribulus terrestris and Zornia glochidiata.

\section{Present-day land use}

Subsistence is based on a wide variety of farming and pastoral activities and on fishing (De Leeuw et al. 1972). Distinct variations in soil patterns are used by the peasants 

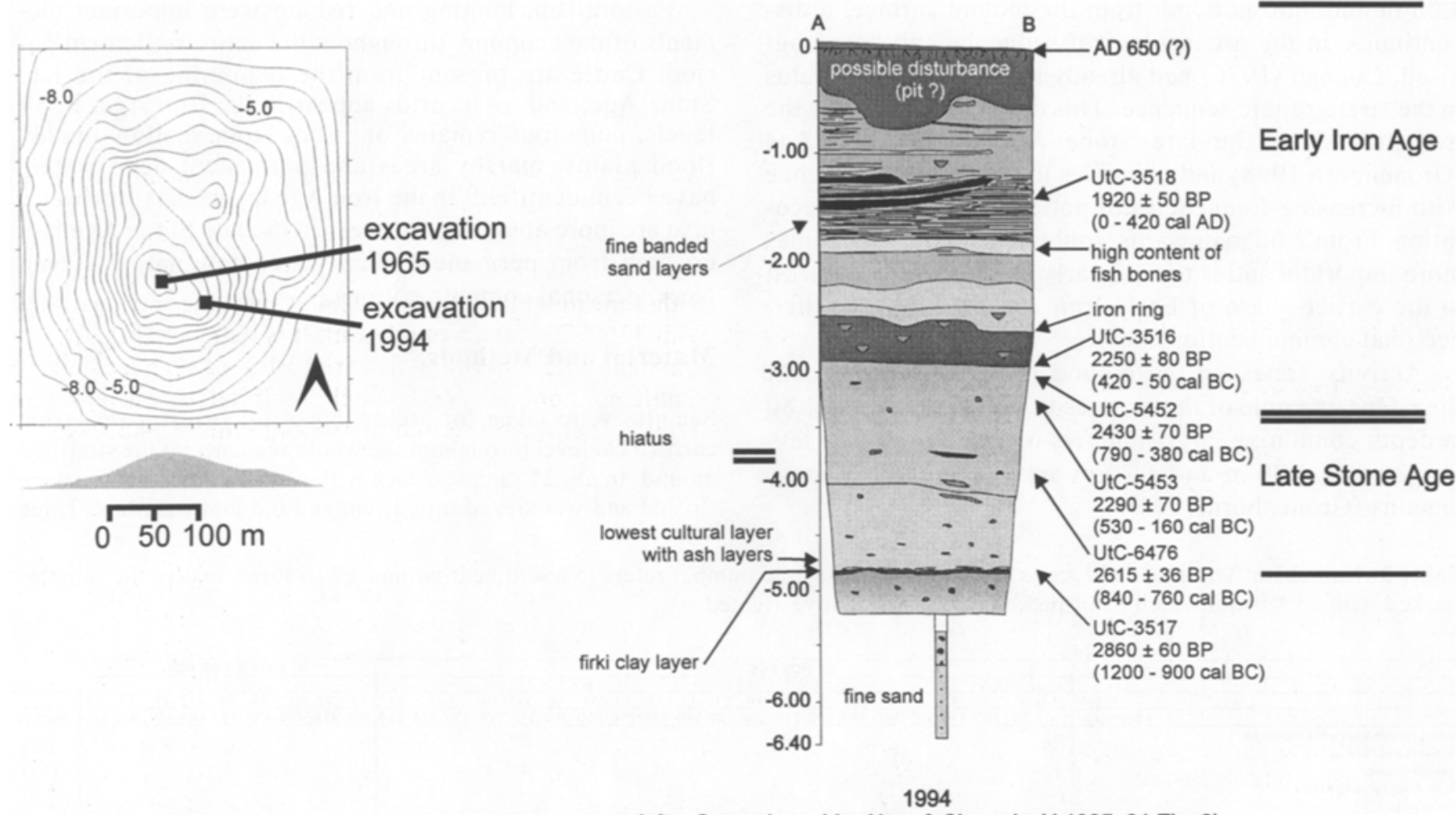

(after Gronenbom, Van Neer \& Skorupinski 1995, 31 Fig. 2)

Fig. 3: Kursakata: Profile of the excavated trench

with regard to their properties for arable farming (Kirscht and Skorupinski 1996, Sturm et al. 1996). Several soil types with different vegetation cover can be distinguished in a series from the elevated sandy places to the flooded clay plains. Depending on the proportion of clay and sand, the water retention and fertility of the soil vary. Rain-fed cultivation with Pennisetum glaucum is limited to the sandy areas, whereas the cultivation of dry-season sorghum (masakwa) is widely practised on seasonally inundated clay soils (Zach et al. 1996). Near Kursakata, both crops can be cultivated as it is situated on the border between sandy soils and the inundated clay plain.

Besides indigenous plants, Chad Basin farmers cultivate a variety of introduced crops. Their later history has been discussed by Blench (1997), who states that "the European crops of Near Eastern origin (Triticum aestivum and Hordeum vulgare) were introduced via the Sahara during medieval times".

Pastoral systems vary in the extent of mobility and sedentism required (Braukämper 1995; De Leeuw et al. 1972). At the beginning of the rainy season, pastoralists migrate westwards, build rainy-season camps in the sandy dune areas covered with rich pastures and, later in the year when grasses become scarce there, slowly move back to the seasonal swamps of the firkis, where floodwater grasses offer a valuable livestock fodder. The dry-season camps are finally established close to the shores of Lake Chad (Sturm et al. 1996). Cattle, sheep and goats graze the vegetation from around remaining ponds and on the harvested fields.

As in other parts of West Africa, wild plants are intensively used. Wild rice and Paniceae play an important role as additional sources of carbohydrates. Fruits of wild trees such as Acacia albida, A. senegal, Balanites aegyptiaca, Tamarindus indica, Ziziphus mauritiana and Z. spinachristi are often used. Besides fruits, leaves of many trees and herbs are popular for the preparation of sauces and as animal fodder.

\section{Archaeological and archaeozoological background}

The settlement mound of Kursakata rises up to seven metres above the firki soils. Occupation started around 1000 B.C., and the site was probably abandoned in the first centuries A.D. (Gronenborn 1998, see radiocarbon dates in Table 1). A trench of $2 \times 1 \mathrm{~m}$ was excavated near the top of the mound (Fig. 3).

The initial, late Stone Age settlement seems to have been situated very close to the firki clays, probably right on the edge of the flooded areas (Connah 1976). Between

Table 1: Radiocarbon dates of Kursakata

\begin{tabular}{|c|c|c|c|}
\hline $\begin{array}{l}\text { depth } \\
\text { (meter) }\end{array}$ & $\begin{array}{c}\text { laboratory } \\
n r .\end{array}$ & $\begin{array}{c}\text { uncal. } \\
\text { B.P. }\end{array}$ & calibrated (1s) \\
\hline 1.40 & UtC 3518 & $1920 \pm 50$ & $58-136$ A.D. \\
\hline 3.00 & UtC 3516 & $2250 \pm 80$ & 393 - 192 B.C. \\
\hline 3.00 & UtC 5452 & $2430 \pm 70$ & $760-399$ B.C. \\
\hline 3.30 & UtC 5453 & $2290 \pm 70$ & $399-207$ B.C. \\
\hline 3.90 & UtC 6478 & $2615 \pm 36$ & 808 - 792 B.C. \\
\hline 4.80 & UtC 3517 & $2860 \pm 60$ & $1251-847$ B.C. \\
\hline
\end{tabular}

$1,2,5,6=$ charcoal; $3,4=$ Pennisetum grain 
$4.00 \mathrm{~m}$ and $3.50 \mathrm{~m}$ depth from the mound surface, a discontinuity in the archaeological sequence can be recognised. Connah (1976) had already noted a possible hiatus in the stratigraphic sequence. This discontinuity marks the transition from the late Stone Age to the Iron Age (Gronenborn 1998) and coincides in the ceramic sequence with increasing frequencies of pottery with roulette decoration. From $2.00 \mathrm{~m}$ upwards, roulette decoration becomes more important and is termed early Iron Age II in contrast to the earlier phase of Early Iron Age I (B. Wiesmüller, personal communication).

Activity zones on the mound probably shifted over time. One example of these zones is a distinct level at 1.80 $\mathrm{m}$ depth containing large numbers of fish bones. The levels between $1.80 \mathrm{~m}$ and $1.20 \mathrm{~m}$ are interpreted as house remains (Gronenborn 1998).
Pastoralism, hunting and fishing were important elements of the economy throughout the entire settlement period. Cattle are present from the beginning of the late Stone Age, and ovicaprids appear in the Iron Age. In all levels, numerous remains of fishes from shallow muddy flood plains, marshy areas and permanent deep waters have been identified. In the Iron Age layers, shallow water taxa are more abundant, whereas in the late Stone Age layers fish from permanent deep water dominate (W. van Neer, personal communication).

\section{Material and Methods}

Samples were taken for archaeobotanical investigation from each $10 \mathrm{~cm}$ level throughout the whole sequence of the stratified mound. In all, 27 samples, each with a volume of 10 litres, were floated and wet-sieved into $1 \mathrm{~mm}$ and $0.5 \mathrm{~mm}$ fractions. Three

Table 2: Kursakata: The seeds and fruits sequence. Each sample number refers to a sediment volume of 10 litres, except the samples marked with an ${ }^{*}$, from which hand-picked material was investigated

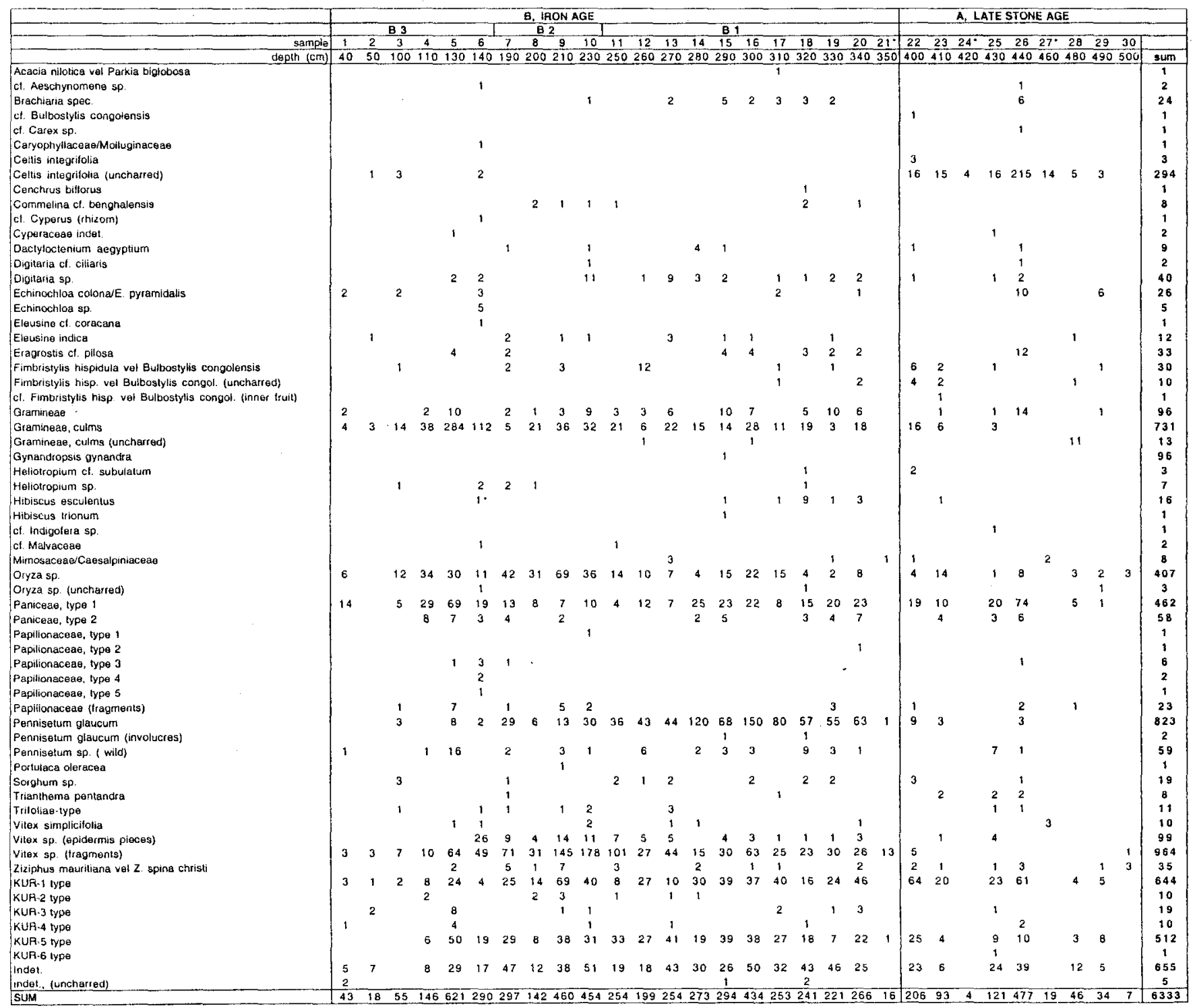


samples $(350 \mathrm{~cm}, 420 \mathrm{~cm}, 460 \mathrm{~cm})$ provided only hand-picked fruit stones. For technical reasons, no samples have been taken from the following levels: $60-90 \mathrm{~cm}, 120 \mathrm{~cm}, 150-180 \mathrm{~cm}, 220$ $\mathrm{cm}, 240 \mathrm{~cm}, 350-390 \mathrm{~cm}, 420 \mathrm{~cm}, 450-470 \mathrm{~cm}$ (see Table 2).

The identification of plant remains is based on the reference collection of the Seminar für Vor- und Frühgeschichte, African Archaeology and Archaeobotany, at the University of Frankfurt. which contains seeds and fruits from 850 species and wood from 520 species. In Table 2, fragments were counted as complete seeds if not otherwise noted. The taxonomy and nomenclature follow FWTA (Flora of West Tropical Africa 1954-1972).

Potsherds from all levels have been investigated. Those from the levels $40-60 \mathrm{~cm}, 340-350 \mathrm{~cm}$, and from $370 \mathrm{~cm}$ are heavily tempered with organic material. In contrast, the other sherds are all mineral tempered and only occasionally show plant impressions on their surface. Casts were made with a silicon based material of low viscosity, as used by dentists (Xanthopren from Bayer). The plant material in the organic tempered potsherds was packed in such dense layers that the number of impressions could only be estimated.

Charred wood was mainly hand-picked from the dry-sieved sediment. In addition. some charcoal fragments were recovered from the wet-sieved samples. Identification was done with an incident light microscope, a slide reference collection of modern Sahelian and Sudanian woods and an interactive identification key based on the computer program package DELTA (Dallwitz et al. 1996, Neumann et al. 2000). The charcoal diagram, giving the absolute fragment numbers for each level. was drawn using the TILIA / TILIA*GRAPH software package (Grimm 1990).

\section{Results; seeds and fruits}

\section{Description of the taxa}

The catalogue of the fruits and seeds including detailed descriptions and discussion of identification criteria will be presented in a forthcoming volume of Vegetation History and Archaeobotany, entitled "Four thousand years of plant exploitation in the Chad Basin of NE Nigeria. II: Fruits and seeds from Kursakata, with special reference to domesticated Pennisetum".

\section{The seeds and fruits sequence}

The soil samples, all containing plant remains, yielded 6333 fragments of seeds and fruits (Table 2). Most of the seeds, fruits and culms are charred (95\%), while $5 \%$ are preserved uncharred. Around $35 \%$ of the remains could not be identified to family or to genus level, and of these $10 \%$ are from one morphological type of seeds or fruits (KUR-1 type), $11 \%$ are culms and 14\% unidentified remains from kernels.

The number of plant remains per sample varies between 4 and 621 . The poorest samples (with less than 50 remains) are from the lowest level (below $440 \mathrm{~cm}$ ) and uppermost level (above $40-100 \mathrm{~cm}$ ). The average density of finds is 21 remains per litre. No exceptionally high concentration of remains has been observed which might be regarded as a closed assemblage (after Willerding 1991; Jacomet et al. 1989). Fortunately, organic-tempered potsherds are available from some levels for which there are no soil samples. Of the 1500 potsherds which have been examined, 977 impressions have been counted on 47 sherds (Table 3 ).

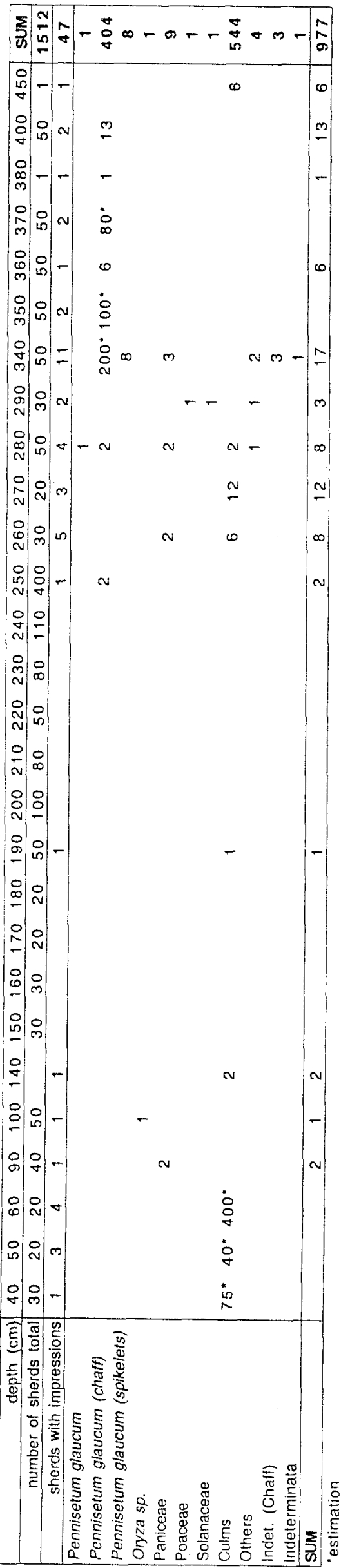



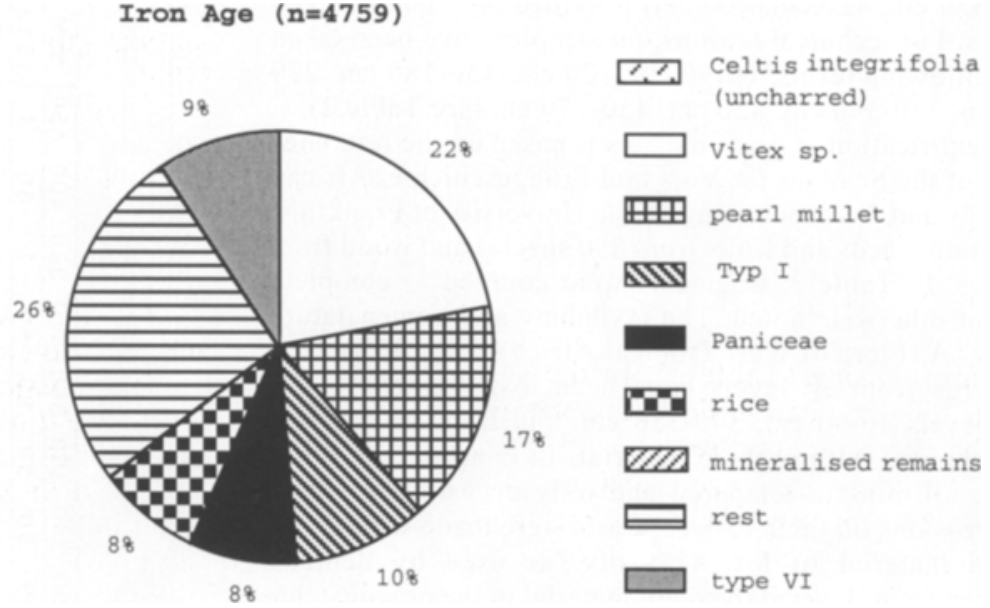

Fig. 4: Kursakata: Percentages of the taxa

A total of 54 taxa or types of seeds and fruits have been identified. Pennisetum glaucum, Paniceae, Oryza sp., Vitex sp. and Celtis integrifolia are present in large numbers. The unidentified taxon called KUR-1 type and culms are also abundant. Of all remains, Vitex sp. fragments occur in the greatest numbers. Some nearly complete kernels could be identified as Vitex simplicifolia. The groups Oryza sp., Paniceae and KUR-1 type each comprise several species which are treated together as one taxon.

The archaeobotanical sequence can be divided into two parts corresponding with two cultural units: The lower unit A (below $390 \mathrm{~cm}$, dated from around $1000-800$ cal. B.C.) is attributed to the late Stone Age and the upper unit B (above $400 \mathrm{~cm}$, dated from around $800 \mathrm{cal}$. B.C. - cal. A.D. 100) to the Iron Age (Gronenborn 1998; Connah 1981). The density of finds and the number of taxa differ: nine soil samples from the late Stone Age layer between
500 and $400 \mathrm{~cm}$ yielded 1051 plant remains, and 5570 remains have been counted in 21 samples from the Iron Age layer above $400 \mathrm{~cm}$. The average density in the lower layer is 15 remains per litre and in the upper layer 26 remains per litre.

The late Stone Age layer is characterised by uncarbonised fruit stones of Celtis integrifolia, carbonised fragments of unidentified fruit stones, wild Paniceae and KUR-1 type seeds. $83 \%$ of the uncharred finds were found here. Paniceae were four times more abundant than Oryza (Fig. 4). Pennisetum was recovered only in very small quantities. The density of remains is generally very low.

The Iron Age layer above $400 \mathrm{~cm}$ is characterised by pearl millet, Vitex sp. and wild grasses, such as Paniceae and rice, the latter two with comparable percentages (Fig. 4). The amount of culms is remarkable. Seeds of KUR-1

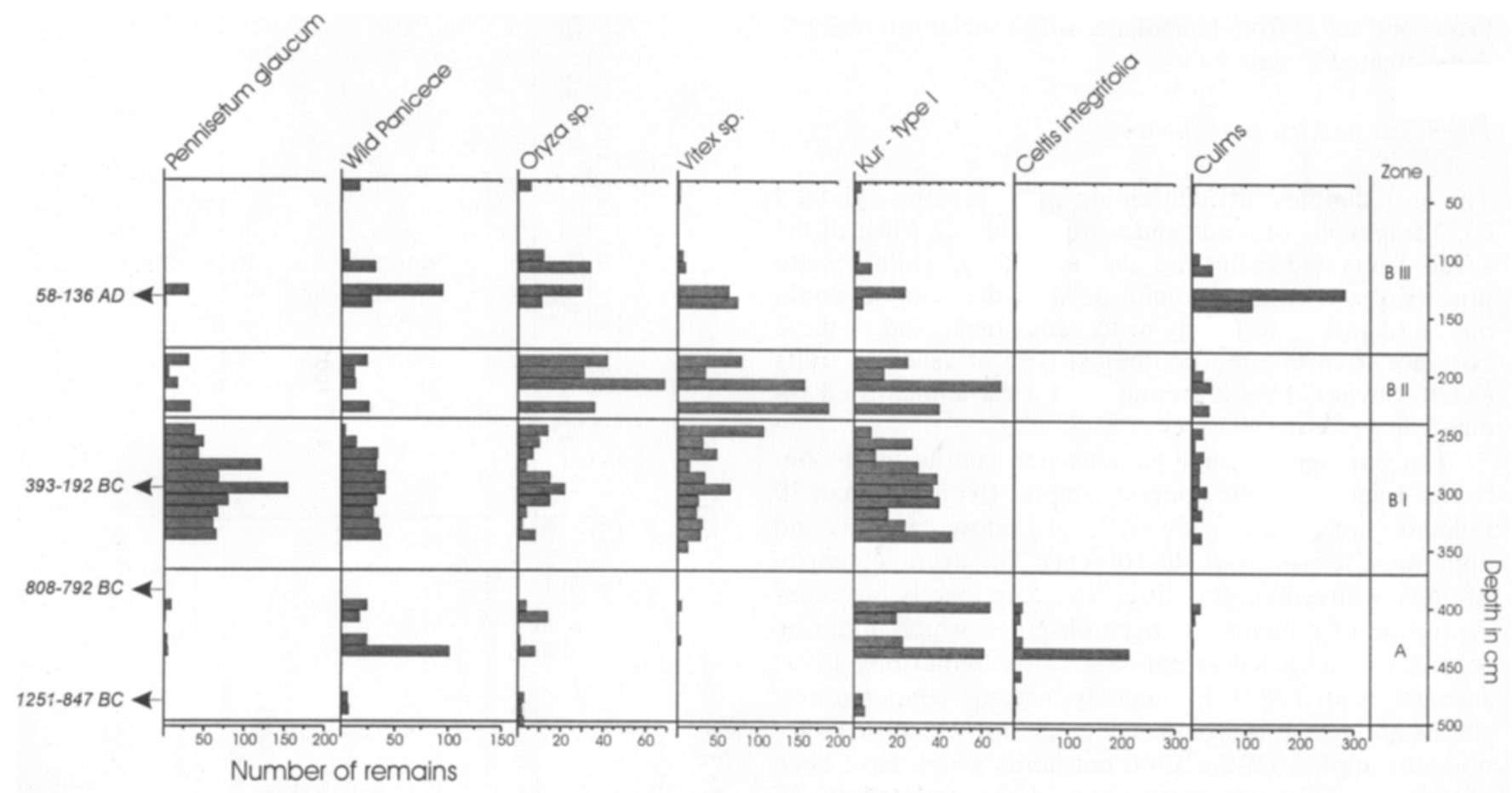

Fig. 5: Kursakata: Occurrence of the main taxa in absolute numbers through the sequence 
type are also very common but less numerous than in the late Stone Age layer. Nearly all remains are carbonised; uncharred ones are very rare.

Three subgroups can be identified in the Iron Age layer (Fig. 5): subunit B1 $(370-250 \mathrm{~cm})$, subunit B2 $(250 / 230$ $190 \mathrm{~cm})$ and subunit B3 $(190 / 140 \mathrm{~cm}$ to the surface). Domesticated pearl millet is dominant in B1 between $370 \mathrm{~cm}$ and $250 \mathrm{~cm}$. Hundreds of spikelets of Pennisetum glaucum have been identified in the organic-tempered potsherds of the levels from $370 \mathrm{~cm}$ to $340 \mathrm{~cm}$, for which soil samples are missing (Table 3 ). In the soil samples from $340 \mathrm{~cm}$ to $250 \mathrm{~cm}$, pearl millet reaches high values of up to $70 \%$ of the charred cereal remains $(P$. glaucum, Paniceae and rice). Paniceae are present with ca. $20 \%$ and rice with $10 \%$. From $240 \mathrm{~cm}$ upwards, domesticated $P$. glaucum decreases to $10-20 \%$, whereas the proportion of rice increases (Fig. 5). The amount of rice and Vitex (some of it identified as $V$. simplicifolia) is remarkably high in $\mathrm{B} 2$ between $250 \mathrm{~cm}$ and $190 \mathrm{~cm}$. In B3, above $200 \mathrm{~cm}$ charred culms are dominant (see Results, B, The charcoal sequence). Paniceae and wild rice are still frequent, whereas pearl millet occurs sporadically in small amounts. The potsherds in the uppermost levels are also tempered with culms.

\section{Results; charcoal}

\section{Description of the taxa}

As most of the taxa found in the samples have already been described in a previous publication (Neumann et al. 1998), only two new charcoal finds are presented. Both taxa are very abundant in the samples: Kigelia africana and Vitex $\mathrm{sp}$. The description follows the IAWA character list (IAWA Committee 1989), modified for DELTA (Richter and Trockenbrodt 1995).

Kigelia africana, Bignoniaceae (Fig. 6a-c)

Growth rings not visible. Vessels solitary and in small radial groups of 2, more rarely in clusters, tangential diameter up to $150 \mu \mathrm{m}$, often with globular inclusions partly or completely filling the lumen; perforations simple, intervessel pits alternate, $5-7 \mu \mathrm{m}$ in tangential diameter, not vestured, vessel ray pits similar to intervessel pits. Fibres thin to medium thick-walled, sometimes with a distinct radial pattern, not septate. Parenchyma confluent to broadly banded, more rarely aliform, in short strands. Rays $1-4$ cells wide, less than $500 \mu \mathrm{m}$ high, heterocellular, composed of short procumbent and square/upright cells. No storied structure and no crystals observed.

Diagnostic remark: from the cross section, this wood might be confused with several Leguminosae (Fabaceae). Nevertheless, only few Leguminosae have heterocellular rays, and Kigelia clearly differs from them in its pit structure: in contrast to Leguminosae, the pits of this wood are not vestured. However, as this character can unequivocally only be observed in SEM, separation from Leguminosae might be difficult, especially when they appear in the same sample. Therefore, an undifferentiated Leguminosae/Bignoniaceae type has been given in the species list.

Vitex sp., Verbenaceae (Fig. 6d-f)

Growth rings not visible. Vessels solitary and in small radial groups, more rarely in clusters, tangential diameter up to $150 \mathrm{im}$, often with thin-walled tyloses; perforations simple, intervessel pits alternate, ca. $5 \mathrm{im}$ in tangential diameter, not vestured, vessel ray pits and vessel parenchyma pits with reduced borders, distinctly larger than intervessel pits, mostly elongate. Fibres thin to medium walled, sometimes in radial rows, septate. Parenchyma paratracheal scanty, often hardly discernible from thinwalled fibres. Rays up to 5-seriate, heterocellular, composed of short procumbent celis with one marginal row of square/upright cells, or mixed short procumbent and square/upright cells; sheath cells present. No storied structure and no crystals observed.

Diagnostic remark: Vitex sp. can be easily confused with Bridelia (Euphorbiaceae). Both genera contain several species and are quite variable. Based on pit structure, observed in SEM, distinction is possible. In contrast to Bridelia, the pits of Vitex are not vestured. At present, wood of Vitex sp. cannot be identified to species level.

\section{The charcoal sequence}

A total of 1469 charcoal fragments has been identified from 29 levels $(490 \mathrm{~cm}$ to $190 \mathrm{~cm}$, Fig. 7). In the levels above $190 \mathrm{~cm}$, no identifiable charcoal was found. Common taxa are Mitragyna type, Acacia nilotica, Prosopis africana, Vitex sp., Ziziphus sp. and Kigelia africana. Minor taxa are Capparis tomentosa, Celtis cf. integrifolia, Securinega/Hymenocardia, Khaya sp., Acacia raddiana type, Balanites aegyptiaca, Acacia albida, Tamarindus sp., Maerua crassifolia and cf. Bauhinieae.

The profile can be clearly divided into a lower unit $A$ (from 490 to $390 \mathrm{~cm}$ ) and an upper unit B (from 380 to 190 $\mathrm{cm})$. This division corresponds with the fruits and seeds sequence and the archaeological differentiation between the late Stone Age and the Iron Age layers. With regard to the charcoal results, the most distinctive difference between the two units is the presence of Mitragyna type in all samples from $\mathrm{A}$, in contrast to its complete absence in B. Celtis cf. integrifolia and Capparis tomentosa show a similar distribution. The absence of Acacia albida in A and its presence in $B$ cannot be interpreted as significant as the sample size is generally too small in A. Above 190 $\mathrm{cm}$, no charred wood is present, and the "thick bands of charcoal" described by Gronenborn (1998, p 233) consist almost completely of culms, possibly the remains of roofs from houses which burnt down several times.

The woody taxa belong to three ecological groups, based on their habitat requirements (after v. Maydell 1983; De Leeuw and Tuley 1972; Aubréville 1950). The majority grow in moist to wet habitats, along rivers and streams or temporarily inundated soils. Only Prosopis africana, Balanites aegyptiaca, Maerua crassifolia and Acacia albida, the second group, grow on well-drained sandy soils. A third group consists of undifferentiated taxa which, due to the low identification level, cannot be attributed to a specific habitat. The Acacia raddiana type contains several species growing on sand, such as $A$. raddiana or $A$. senegal, and others found in wet places, such as $A$. seyal. As $A$. seyal is the most abundant species on the firki clays today, it seems reasonable to attribute the charcoal to this species.

\section{Discussion}

Taphonomy and methodological problems

The assumption of plant use is based on the frequent and abundant occurrence of their diaspores in a subfossil as- 

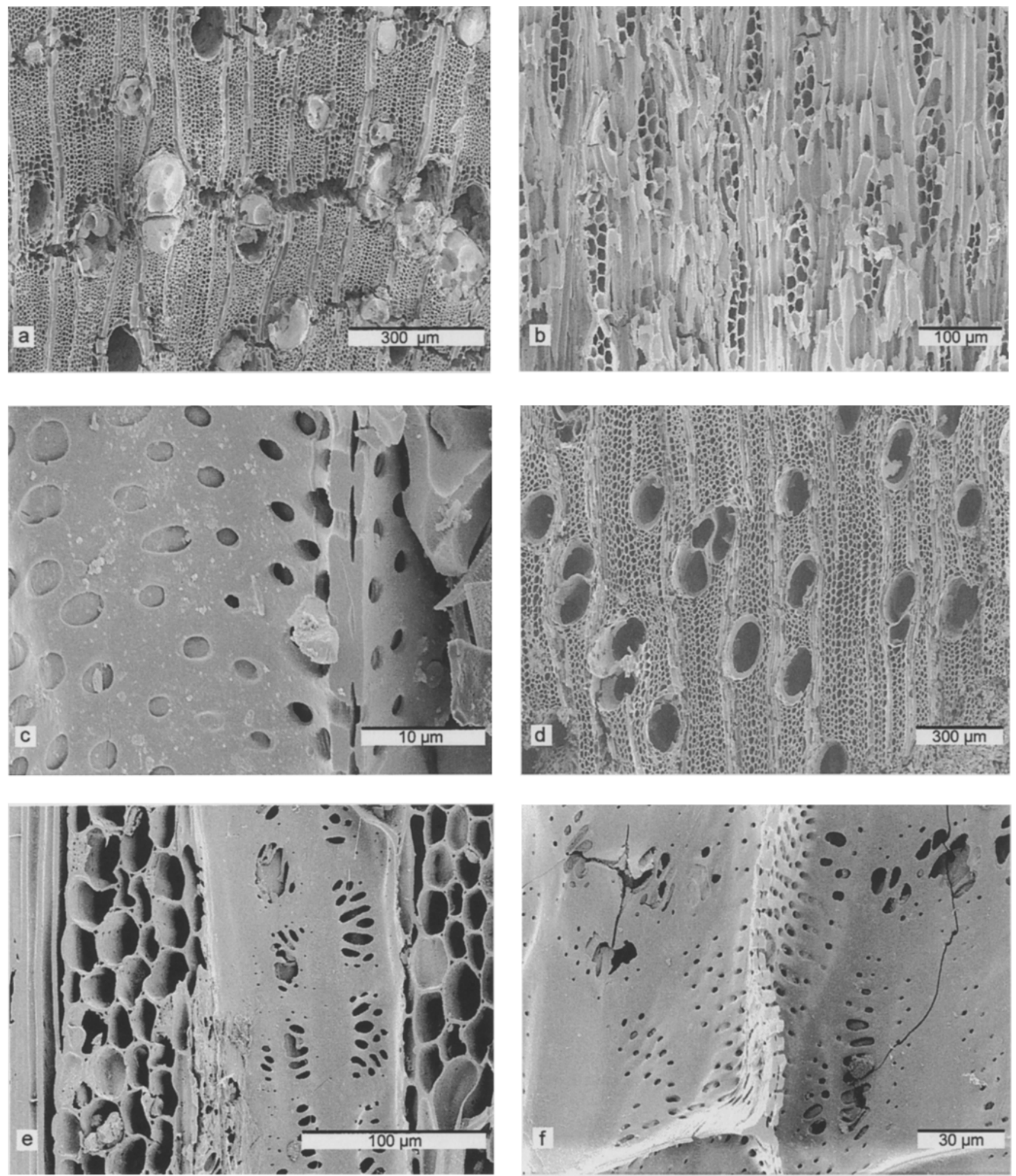

Fig. 6: Kursakata: SEM photographs of charcoal, a) Kigelia africana, cross section, b) $K$. africana, tangential section, c) $K$. africana, radial section, non-vestured intervessel pits, d) l'itex $\mathrm{sp}$., cross section, e) Vitex sp., tangential section, simple vessel-parenchyma pits and septate fibres, f) Vitex sp., radial section, non-vestured intervessel pits

semblage. We think that all charred remains result from plants which were brought intentionally into the settlement for human use. An exception is probably the ruderal weed flora, which might have grown either within the settlement or outside it in association with wild cereals, with which they were gathered and thus brought into the village acci- 
dentally. Together with the collected wild plants, the weeds represent a part of the natural composition of the surrounding herbaceous vegetation. Uncharred remains like Celtis integrifolia fruit-stones as well as the uncharred taxa (such as Fimbristylis hispidula or Bulbostylus congolensis) might originate from the local vegetation of the settlement area. It would be interesting to know whether some of the seeds represent weeds from pearl millet fields. Candidates are the taxa which grow on sandy soils. In the absence of a closed assemblage, we cannot reconstruct a real palaeocoenosis (the original combination of a growing plant community).

Our results shed light on the development of the settlement and environment of Kursakata. However, as only two square metres have been excavated, the potential for representative hypotheses concerning the whole mound is limited, the location of activities can change in the course of occupation. Therefore, our interpretation of agricultural practices and plant use and their changes through time is preliminary and needs further confirmation by data from comparable sites.

\section{Palaeoethnobotany}

1. Domesticated cereals. Among the identified plants Pennisetum glaucum, the domesticated form of pearl millet, is the only cultigen. This indigenous African cereal, interfertile with wild races, is a free-threshing and selfpollinating diploid crop which can grow under a minimum annual rainfall of $250 \mathrm{~mm}$ (Harlan 1989b, Brunken et al 1977).

No charred threshing remains of pearl millet besides two involucres, such as bristles or spikelets, have been found. Perhaps the fragile bristles did not survive the archaeobotanical sieving procedure, but then the more robust parts of the ear should have been found if they had ever come into contact with fire. Our study of remains of modern African pottery, oven fired with pearl millet straw, revealed that ears, bristles, involucres and a few grains were well preserved. Hence it can be expected that these charred parts would also be preserved in fossil assemblages. In the ceramic impressions from Kursakata, the presence of bristles and involucres indicates that threshing remains of Pennisetum glaucum were used for tempering. The absence of bristles and spikelets might be due to threshing which may have been done elsewhere in the settlement or chaff may not have been burnt.

The small size of all pearl millet grains is surprising. They just reach the size of the smallest modern grains of specimens with ears only $4 \mathrm{~cm}$ long, as studied in the Herbarium of the Botanical Garden and Botanical Museum at Berlin. Today, even the grains of hybrids between domesticated pearl millet and weedy races (called shibras) are usually larger than the archaeological specimens. This phenomenon cannot be sufficiently explained by shrinking during the carbonisation process. Hence it seems likely that the subfossil grains represent an early stage of domestication.

According to Harlan (1971), pearl millet was probably domesticated in a broad belt at the southern margins of the Sahara. If the domestication area included the firki plains, and if the first domestication phase were represented in Kursakata, we would expect to find a mixture of wild and small domesticated forms. As wild Pennisetum grains can hardly be found in our samples, an introduction of this cultigen from outside the firki area seems mosit likely.

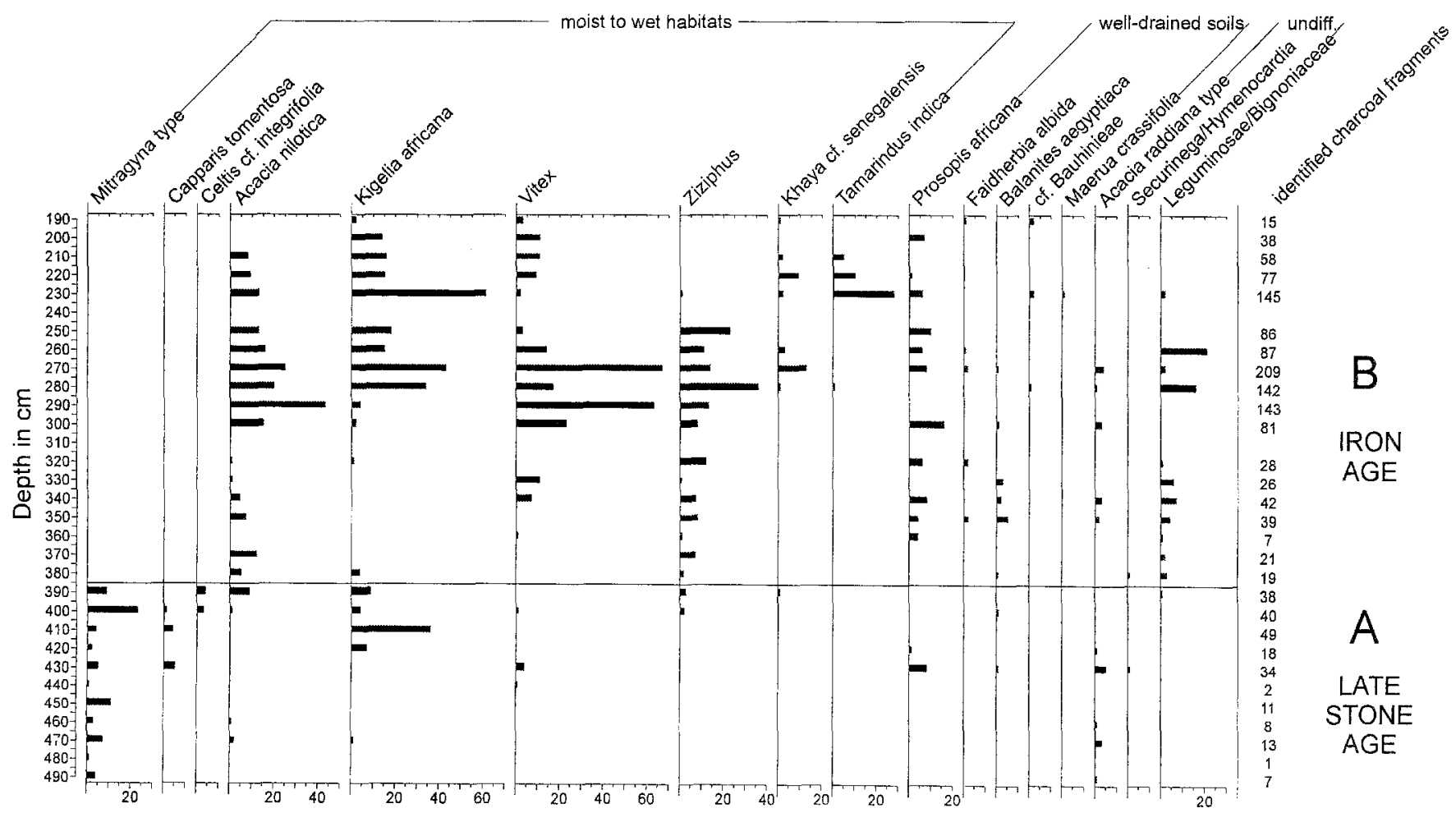

Analysis: K. Neumann \& D. Uebel

Fig. 7: Kursakata: The charcoal sequence, absolute numbers of fragments 
Archaeobotanical evidence for Pennisetum spp. and its early domestication history is still very scarce. The earliest finds are reported from Dhar Tichitt in Mauretania, on the southern fringes of the Sahara, where wild and domesticated forms have been found as impressions in ceramics (Amblard 1996; Amblard and Pernès 1989; Jacques-Felix $1971)$ dated to around 3500 B.P. (1800 cal. B.C.). Domesticated $P$. glaucum has been identified in potsherds from Karkarichinkat in the Lower Tilemsi Valley (Mali) with an uncertain age of probably 3300 B.P. (Smith 1974, 1972). Charred grains of domesticated P. glaucum are present in Tin-Akof and Oursi (Sahel of Burkina Faso), both with a date of around $1000 \mathrm{cal}$. B.C. (Kahlheber et al. in press; Vogelsang et al. 2000; Neumann 1999a). The earliest impressions of domesticated $P$. glaucum in potsherds from Gajiganna, $100 \mathrm{~km}$ to the west of Kursakata, are dated to 1200-1000 cal. B.C. (Breunig and Neumann 1999; Klee and Zach 1999). As in Kursakata, the grains from TinAkof, Oursi and Gajiganna are also rather small.

It remains unclear whether in earlier times wild Pennisetum spp. were widely distributed on the sandy areas around Kursakata. The presence of wild Sorghum sp. in some levels points to $S$. aethiopicum stands, which presumably covered the firki plains as described by De Leeuw et al. (1972). However, there is no evidence for intentional harvesting of wild Sorghum sp. and thus it seems most likely that the wild ancestors of both indigenous African crops were not collected in the firki region.

Domesticated Sorghum bicolor has not been found in Kursakata. Preliminary studies at the firki sites Daima (Connah 1981, pp 188 f) and Mege (Klee and Zach 1999, Zach et al. 1996) revealed that it was not introduced into this area before A.D. 800, when the settlement of Kursakata had already been abandoned.

2. Collected wild cereals: rice and Paniceae. Wild cereals played a major role as a source of carbohydrates at Kursakata. Numerous grains of Paniceae and Oryza sp. are present in all levels, but no threshing remains or grains in glumes have been found. Following Wasylikowa (1997), we consider an accumulation of one type of grass in an archaeological context as an indication of its purposeful collection. Like pearl millet, wild grasses might have been cleaned and prepared for cooking. A lot of ethnographic information is available on harvesting of grasses (see Burkill 1985-97). Grains of wild grasses were a major part of the diet up to the 19th century (Harlan 1989a) and are still collected today. In years with sufficient rainfall the grains of wild grasses are only used as food in addition to the staples sorghum and pearl millet. In droughts their availability becomes crucial to survival (Harlan 1989a).

The rice from Kursakata is assumed to be wild because some of the subfossil grains resemble Oryza longistaminata. However, the identification of rice grains remains problematic, as no reliable features have yet been described in the taxonomic literature. The Asian rice $O$. sativa was introduced in the last 500 years (Burkill 1994). Important indigenous rice species are the wild $O$. barthii and $O$. longistaminata and the domesticated African rice $O$. glaberrima. The annual $O$. barthii frequently grows in shallow, temporarily flooded depressions, whereas the perennial $O$. longistaminata is restricted to permanent wa- ter bodies (Harlan 1989a). Today, wild rice is commonly collected by women in the firki plains and sold at the markets.

Among the numerous remains of Paniceae four genera could be identified. Digitaria, Brachiaria and Echinochloa are most abundant and thus regarded as collected cereals. However, given the current state of taxonomic knowledge, identification to species level is not possible. Cenchrus and Eleusine, a member of the tribe Eragrostidae, are represented only by scattered finds.

Nevertheless, it is obvious that Paniceae were a staple food of the Kursakata people. Today, a mixture of several Paniceae, named either acha, kasha or kreb, are sold at local markets. In the last century, European travellers mentioned the harvesting of $k r e b$ in the Lake Chad area (Nachtigal 1881; Barth 1857). Kreb is a mixture with variable proportions of small Paniceae grains including Panicum, Brachiaria and Echinochloa (such as E. pyramidalis, E. stagnina).

3. Tree fruits. The edible fruits of the trees Vitex simplicifolia, Celtis integrifolia and Ziziphus mauritiana or $Z$. spina-christi were frequently encountered besides numerous kernel fragments of Vitex $\mathrm{sp}$. and the unidentified fragments of fruit stones. Vitex is the most abundant fruit tree. Today, Vitex simplicifolia grows in Sudanian and Guinean savannas. Its habitat extends to the southern Sahel in areas with a high groundwater table. The fruit pulp is edible and twigs are regularly used as chewsticks (v. Maydell 1983; Irvine 1961). The large number of carbonised fragments of Vitex sp. in the samples suggests that the kernels were either involved in a roasting process or were thrown as waste into the fire. However, up to now we do not know of any ethnographic examples of roasting of the kernels.

Many Celtis integrifolia fruit fragments were recovered in the lower levels of the late Stone Age. Celtis is a Sudanian tree which also grows extrazonally along rivers and depressions in the Sahel. Since nearly all kernels were uncarbonised, there is no evidence for their use in cooking or any other preparation method using fire. It remains unclear why they are absent from the Iron Age layer. We can either assume that the fruits, which ripen in the late dry season, were brought in from outside and eaten fresh on the spot, or that a Celtis tree was growing in the settlement. It is also possible that the fruits came in unintentionally with branches cut for their leaves, which were used for human consumption or as animal fodder. Several ethnographic examples of Celtis leaf foraging have been described by v. Maydell (1983) and Irvine (1961). Charred wood of C. integrifolia occurs only sporadically in the levels around $400 \mathrm{~cm}$.

In contrast to Celtis integrifolia, charcoal remains of Ziziphus mauritiana or Z. spina-christi are frequently found, although fruit fragments are rare. $Z$. mauritiana tolerates great heat and drought and does not require specific soil although not usually growing on clay. Both species can grow on periodically inundated sites and on the edges of depressions (v. Maydell 1983). The fruits of $Z$. mauritiana ripen in the dry season and are eaten fresh or dried. In the Sudan, people use the pulp and crush the stones to extract the kernels, which are ground to flour 
(Tubiana and Tubiana 1977). Today, both species can be found around Kursakata and in comparison to Celtis, the fruits of Ziziphus are clearly preferred by the people. It may be that fragments of these fruits are hidden in the bulk of unidentified fruit stone fragments which were found in every level.

One charred seed of Parkia biglobosa or Acacia nilotica has been found in the $310 \mathrm{~cm}$ level. It is likely that it belongs to $A$. nilotica, the charcoal of which is present throughout the sequence. A. nilotica and P. biglobosa are trees with a large utilisation potential.

The lack of fruit remains of the recently very common species Balanites aegyptiaca is notable. The charcoal finds of $B$. aegyptiaca indicate that the tree was present in the surroundings. However, the subfossil assemblage of carbonised seeds and fruits only partly represents the spectrum of used plants depending on carbonisation.

4. Other useful plants. Carbonised seeds of Hibiscus esculentus (ochra) regularly occur in low numbers in the levels between 290 and $340 \mathrm{~cm}$. Ochra is commonly used today and was cultivated in Egypt at 2000 B.C. (Burkill 1985-1997). The unripe fruits are used for sauce or soup. In northeast Nigeria, the seeds are prepared into food and the roasted seeds are used as a substitute for coffee. It is perhaps a cultigen derived from a selection of $H$. ficulneus (Burkill 1997). H. esculentus also grows on fallow land or at the edges of fields where the so called "wild" fruits are gathered.

One Cyperus sp. rhizome has been found which could not been identified to species level. It closely resembles one of the Cyperus species used for nutrition or for its aromatic properties such as $C$. esculentus or $C$. rotundus.

5. Culms. Fragments of grass culms have been found in almost every level from $430 \mathrm{~cm}$ upwards. The bulk of carbonised remains in the upper levels above $140 \mathrm{~cm}$ consists of culms. Potsherds are heavily tempered with this material. Besides two involucres of Pennisetum glaucum neither any threshing material from cereals nor processing remains from gathered wild Paniceae and rice were found, so it has to be assumed that food processing is not the reason for the frequent occurrence of the culms. One explanation, supported by ethnographic analogy in the surrounding of Kursakata today, is the use of straw of wild Pennisetum spp. and other grasses for roofing. There is also archaeological evidence in the culm-rich levels of houses which probably burnt down several times (Gronenborn 1998).

\section{Ecological considerations}

The recorded herbaceous plants can be classified according to their ecological requirements as demonstrated by their actual habitats. Dry, sandy soils are the usual habitat of wild and domesticated Pennisetum species, Cenchrus biflorus, Dactyloctenium aegyptium, Heliotropium cf. subulatum, the latter three on fallow land and pastures and Trianthema pentandra. On the temporarily inundated floodplains Echinochloa pyramidalis, E. colona, Oryza barthii, $O$. longistaminata and Sorghum aethiopicum grow. Weeds on cultivated land, on disturbed places or fallow land are Commelina spp., Eleusine indica, Eragrostis cf. pilosa, Hibiscus trionum and Gynandropsis gynandra (Burkill 1985-1997).

The woody vegetation and its use

In the charcoal diagram, the large number of woody taxa belonging to moist or wet habitats is remarkable. Some of them are also represented by fruits, such as Vitex, Ziziphus and Celtis. This clearly reflects an environment dominated by water as is typical of the Chad lagoonal complex with its firki clay soils. Although Kursakata is situated on sand on the Ngelewa beach ridge, the occurrence of sandy soils is restricted. This is reflected by the low number of fossil taxa, which grow on well-drained soils. In comparison with a settlement mound in a dune area of Burkina Faso, where 30 woody plants have been recorded (Neumann et al. 1998), only 15 taxa were found at Kursakata. This points to peculiar environmental conditions where only specially adapted plants can flourish.

Only a smaller part of the firewood was collected on the well-drained sandy soils of the Ngelewa beach ridge in the immediate vicinity of the settlement (Prosopis africana, Acacia albida, Maerua crassifolia and Balanites aegyptiaca). This can partly be explained by the limited extent of the ridge itself. However, the scarcity of woody vegetation on the dunes in general seems to be a more reliable explanation. With the exception of a few fragments of Bauhinieae (a wood type including Piliostigma spp.), no plants of fallow land - such as Combretum glutinosum and Guiera senegalensis - have been found. This could indicate either that there were no fields and fallow land in the area, or that millet was planted on permanent fields and not in a shifting cultivation system. Perhaps most woody plants in the immediate vicinity of the settlement were removed and only a few remained, possibly protected or even cultivated.

If we compare the modern, almost treeless firki with the woody vegetation reconstructed for the period between 1000 B.C. and A.D. 100 at Kursakata, the differences are considerable. Even during the early Iron Age, when the climate was supposedly drier than before, the vegetation was much richer than today and included Sudanian elements like Vitex, Kigelia africana and Khaya. Today the firki at first sight seem to be a hostile environment for woody plants because of their clay soils which are usually regarded as unfavourable for tree growth. However, there are distinct variations in soil patterns (Thiemeyer 1997, pp $66 \mathrm{ff}$; Kirscht and Skorupinski 1996; Sturm et al. 1996; De Leeuw and Tuley 1972, p 114) which might have resulted in a mosaic-like distribution of woody formations and grasslands in the past. Several woody communities probably existed especially on firki soils with higher sand contents, called motusku (Kirscht and Skorupinski 1996) and in those places where the underlying Pleistocene dunes are lying near to the surface (see De Leeuw and Tuley 1972, p 114). Comparable modern communities have been described by De Leeuw and Tuley $(1972, \mathrm{pp} 151 \mathrm{ff}$ ) as "riparian woodland" with Mitragyna inermis, Acacia nilotica, Kigelia africana, Celtis integrifolia, Khaya senegalensis, Vitex simplicifolia and several Acacia species, but these are only found outside the Chad lagoonal 
complex. In the Chadian part of the Chad basin several of the taxa mentioned above occur either along rivers and streams or in depressions with temporarily inundated soils (Pias 1970, pp 20 ff.). However, Acacia seyal is dominant in the modern dense woody formations on clay soils (Grondard 1964, p 26), whereas Kigelia africana, Celtis integrifolia, Khaya senegalensis and Vitex simplicifolia only grow further south under higher rainfall. The woody plant communities on the firki in Cameroon are also dominated by Acacia seyal, with occasional admixtures of other species (Letouzey (1968, p 321 ).

Although dense woody formations existed in the firki around Kursakata, there are indications that their distribution was limited. Two of the dominant taxa, Vitex sp. (v. Maydell 1983, but see Irvine 1961 for the opposite view) and Kigelia africana (Irvine 1961), are known for their inferior quality as firewood. Probably for this reason, wood of Vitex sp. is missing from archaeological sites of Burkina Faso (Neumann et al. 1998) whereas its fruit remains are generally well represented. As the inhabitants of Kursakata collected most of their firewood from these species, it can be suggested that not enough high-quality fuel was available. This hypothesis is supported by the comparatively uniform distribution of the woody taxa in the charcoal samples, indicating a non-selective collecting behaviour typical of people living in an environment with limited fuel resources (Neumann 1999b).

Today, the species-rich woody formations have completely vanished from the firki region of northeast Nigeria. It is remarkable that the Acacia raddiana charcoal type, which probably represents $A$. seyal, is rare in the samples whereas this species is dominant today in the remaining woodlands on the firki. For the impoverishment of the vegetation through time, several hypotheses can be formulated: first, the tree cover of the firki was largely destroyed when sorghum cultivation started on the clay soils in medieval times, since the farmers preferred those soils for cultivation which are also favourable for tree growth. Secondly, the Sudanian taxa were eliminated from the woody communities as a consequence of increasing aridification. Thirdly, rich woody communities persisted up to historical times and were only cleared during the last decades in the frame of the "South Chad irrigation project" for largescale irrigated cereal production. For testing these hypotheses, additional archaeobotanical data from other sites in the firki would be needed.

\section{Palaeoenvironment and economy}

1. The late Stone Age. In comparison with the early and middle Holocene, the climate from 1000 B.C. onwards, when the firki plains became accessible, was relatively dry. However, the environment of Kursakata during the first settlement phase (the late Stone Age from ca. 1000 to 800 B.C.) was still characterised by water. The charcoal analysis shows that some trees from wet habitats were growing in the surroundings, possibly including Mitragyna inermis in depressions inundated for several months of the year.

According to Gronenborn (1998) the settlement was located close to a large lagoon. The assumption that the site was only seasonally occupied (Gronenborn et al.
1996) is supported by the small amount of botanical remains, indicating scarce settlement activities in the late Stone Age. The few finds of pearl millet and the much greater number of gathered wild cereals and fruits support the hypothesis of a seasonal occupation without agricultural activities in the area. Maybe the site was only used in the dry season, when water levels were low. The permanent water fish Lates which is present in the faunal remains (Gronenborn 1998), was caught in addition to fish from shallow muddy flood plains and from marshy, vegetated areas (W. van Neer, personal communication). Cattle grazed along the edges of the numerous ponds on the firki plains. From the available organic remains, Connah (1981, p 98) concluded that "... the subsistence economy of the Kursakata villagers was probably based on mixed farming and some hunting and fishing". Now, as more archaeobotanical, archaeological and archaeozoological data are available, we conclude that the economy was more diversified, and agriculture only played a minor role, in addition to cattle-raising, fishing and the collection of wild grasses.

2. Climatic change and the end of the late Stone Age. The abrupt change in the distribution of the Mitragyna type present in all charcoal samples from the late Stone Age layer (unit A, 490-390 cm) and completely absent from the Iron Age (unit B, $380-190 \mathrm{~cm}$ ), is remarkable. Mitragyna is a wood type of the family Rubiaceae comprising several species and so far imperfectly defined (Neumann et al. 1998). From its phytogeographic distribution and ecological requirements, it can be assumed that the Mitragyna type of Kursakata belongs to $M$. inermis, a SaheloSudanian tree commonly found in depressions with clay soils inundated for several months of the year. $M$. inermis provides excellent firewood (v. Maydell 1983). Therefore its absence from the Iron Age should not be related to changes in selective collecting of firewood, but rather to a decline in species abundance after 2600 B.P.

Even though the Mitragyna type is present at other settlement mounds of the firki up to modern times - such as in Mege, where it was found in a level dated to $365 \pm 66$ uncal. B.P., and in Ngala dated to $1165 \pm 33$ uncal. B.P., respectively - its complete disappearance at Kursakata points to a sudden onset of drier conditions resulting in the desiccation of the seasonal ponds around the site. The two species Capparis tomentosa and Celtis integrifolia - both of which grow in moist habitats - show a similar trend in the charcoal sequence as the Mitragyna type and hence furnish additional evidence for an aridification.

Detailed stratified palaeoclimatic indicators from the Sahel and the Chad Basin for the third millennium B.P. (= the first millennium B.C.) are scarce. There are indications that the late Stone Age cultures of the Sahel witnessed a major crisis during this period. Both in the firki and in the Gajiganna region to the west, an abrupt hiatus in settlement activities can be recorded between 800 and 600 cal. B.C. A similar trend is evidenced from the Sahel of Burkina Faso, where for the first millennium B.C. almost no traces of settlement activities are recorded (Breunig and Neumann 1999). The disappearance of the Mitragyna type at Kursakata coincides with changes in the archaeobotanical sequence, sedimentology, archaeozoolo- 
gical finds and artefacts (Gronenborn 1998), suggesting a close relation between aridification and the end of the late Stone Age culture.

The most recent find of Mitragyna type at the site is dated to $2615 \pm 36$ uncal. B.P., $808-792$ cal. B.C. (UtC5453). Even though comparison of palaeoecological data on a super-regional scale can be misleading if local site conditions are ignored (see Salzmann and Waller 1998), the correspondence with a global phenomenon noted by Van Geel et al. (1998) is remarkable. The authors describe a change towards moister, cooler conditions in Europe around 2650 B.P. (800 cal. B.C.) resulting from reduced solar activity. For tropical Africa a contemporary shift to aridity is suggested which has been supported by re-dating of the pollen profile from Lac Ossa in Cameroon. However, in the pollen diagrams and other palaeoecological data sets from northeast Nigeria, the major change towards aridification is visible between 3800 and 3000 B.P. and not around 2650 B.P. (Holmes et al. 1999; Salzmann and Waller 1998; Salzmann 2000). Further archaeobotanical sequences and other palaeoecological data from the Chad Basin are needed to strengthen or weaken the hypothesis that environmental change in the first millennium B.C. was contemporary with and related to global climatic events.

3. The Iron Age. Our archaeobotanical investigations have shown that the transition from late Stone Age to the Iron Age (between 800 and $400 \mathrm{cal}$ B.C.) was accompanied by the beginning of large-scale farming. Changes in the plant spectra are contemporary with changes in the archaeological sequence (Gronenborn 1998). The site may have been permanently occupied. Since the frequencies of pearl millet are significantly higher than before, it seems most likely that this crop was cultivated on the sandy soils close to the site. However, collection of Paniceae and wild rice was still of great importance.

Cultivation of pearl millet and permanent occupation were presumably possible as a consequence of environmental change towards drier conditions. With decreasing inundation frequencies, larger sandy areas might have became more open and suitable for arable farming. Large amounts of carbonised pearl millet grains were found especially in the oldest levels of the Iron Age, indicating its cultivation on sandy soils near the settlement. The development of agriculture was probably also promoted by technical innovations at the onset of the Iron Age.

In the upper Iron Age levels (above $250 \mathrm{~cm}$ ), pearl millet is only present in small amounts, but wild plants are still recorded. Rice and Vitex sp. become more frequent and may imply a greater economic importance than before. We cannot say whether agriculture lost its importance or whether processing of pearl millet was done in another part of the settlement. However, from the archaeological evidence (Gronenborn 1998), it seems more likely that the shifting of activity zones is responsible for the change in the archaeobotanical spectrum, at least from $190 \mathrm{~cm}$ upwards.

\section{Conclusion}

The availability of rich natural resources especially in the dry season seems to have been an important reason for the first inhabitants of Kursakata to settle near temporary or permanent ponds in spite of the risk that their settlement would become inundated during the rainy season. The rich stands of wild grasses like rice and Paniceae in the seasonally flooded depressions and the firki plain were probably an important factor, not only for human nutrition but also for livestock grazing during the dry season, when the pastures on the sandy soils were desiccated.

The results clearly show that cultivated pearl millet was known from the beginning of the occupation, though there are only a few grains in the lowest late Stone Age levels. Early agriculture in the Chad Basin has also been confirmed by the archaeobotanical data from the Gajiganna region $100 \mathrm{~km}$ west of Kursakata (Breunig and Neumann 1999; Klee and Zach 1999). In both areas there are indications that agriculture and the knowledge of plant domestication were introduced from outside. In Gajiganna this introduction has been dated to $1200 \mathrm{cal}$. B.C., in Kursakata around $1000 \mathrm{cal}$. B.C.

However, it seems that agriculture played a minor role in the late Stone Age, when the site was presumably occupied only during the dry months and activities consisted mainly of fishing, cattle grazing and collection of wild cereals. With the onset of the Iron Age, agriculture gained more importance. This economic change coincided with a permanent occupation of Kursakata, the introduction of iron technology, and a shift to more arid conditions.

A most remarkable feature of the late Stone Age as well as of the Iron Age economies is their great diversity, The exploitation of a wide spectrum of natural resources was a way of minimising the risk of failure. In an area with unpredictable rainfall like the Chad Basin, a mixture of farming and gathering of wild cereals could guarantee a permanent supply of carbohydrates. Therefore the wild grasses, mainly rice and Paniceae, should not only be regarded as additional or famine food, but as a permanent factor in a very flexible, highly adapted subsistence strategy which also included fishing and the keeping of cattle and small livestock.

In comparison with Europe and the Near East, wild grasses play a much more important role in the economies which developed in the African savanna regions. This feature can be observed from the late Stone Age through to modern times and is even reported from medieval urban centres like Great Zimbabwe (Jonsson 1998) or JennéJeno/Mali (McIntosh 1995). Our results show that in the Chad Basin with its rich grass communities, harvesting of wild rice and Paniceae can be traced back to the beginning of the late Holocene occupation which started around 1000 B.C. in Kursakata. Thus, the archaeobotanical data attest to a successful tradition which continued for almost 1000 years.

Acknowledgements. We wish to express our indebtedness to everyone who has made this project possible: Peter Breunig and Detlef Gronenborn, who excavated the site, and Wim van Neer, who undertook the archaeozoological part. Our sincere thanks also to Krystyna Wasylikowa, who studied the Paniceae with us for some days in the Frankfurt Laboratory; to Manfred Bässler of the Herbarium of the Botanischer Garten und Botanisches Museum Berlin Dahlem (B). who patiently helped us through the Herbarium and offered us assistance in whatever way we required and also to Claude Farron of the seed collection of Basel; to Dušanka Kucan in Wilhelmshaven and Urs Weber in Basel 
for photos of the seeds, to Monika Heckner, Barbara Voss and Dirk Uebel for drawings and SEM photographs, to Philippe Hadon for his help with TILIA and to Amy Bogaard for correcting the English manuscript. For fruitful discussions and patience we wish to thank Stefanie Kahlheber, Holger Kirscht, Editha Platte, Ulrich Salzmann, Birgitt Wiesmüller, Gulla Schenk, Angela Schlumbaum and Thomas Skorupinski. Finally, many thanks to all the friendly African labourers who not only worked for the excavation but also told us a lot about the plants.

\section{References}

Aitchison PJ. Bawden MG, Caroll DM, Glover PE, Klinkenberg K. Leeuw PN de. Tuley P (1972) The Land Resources of North East Nigeria Vol 1, The Environment. Land Resource Study 9, Surbiton

Amblard S (1996) Agricultural evidence and its interpretation on the Dhars Tichitt and Oualata, south-eastern Mauritania. In: Pwiti G, Soper R (eds) Aspects of African Archaeology. Papers from the 10th Congress of the PanAfrican Association for Prehistory and Related Studies. University of Zimbabwe Publications, Harare, pp 421-427

Amblard S, Pernès J (1989) The identification of the cultivated pearl millet (Pennisetum) amongst plant impressions on pottery from Oued Chebbi (Dhar Oualata, Mauritania). African Arch Rev 7: $117-126$

Aubréville A (1950) Flore forestière soudano-guinénne. Société d'éditions géographiques, maritimes et coloniales, Paris

Barth H (1857) Travels and discoveries in North and Central Africa, Vol 2. Harper \& Brothers, New York

Blench R (1997) The history of agriculture in Northeastern Nigeria. In: Barreteau D, Dognin R, Graffenried C von (eds) L'homme et le milieu végétal dans le bassin du Lac Tchad. Editions de l'ORSTOM, Paris, pp 69-112

Braukämper U (1995) Probleme der Nutzung von Weideressourcen bei den Shuwa-Arabern im nigerianischen Tschadbecken. Ber Sonderforschungsbereichs 268, 5: 147-162

Breunig P. Neumann K (1999) Archäologische und archäobotanische Forschungen in Westafrika. Archäol Nachrichtenbl 4: 336-357

Breunig P, Neumann K, Neer W van (1996) New research on the Holocene settlement and environment of the Chad Basin in Nigeria. African Arch Rev 13(2): 111-145

Brunken J, Wet JMJ de, Harlan JR (1977) The morphology and domestication of pearl millet. Econ Bot 31: 163-174

Burkill HM (1985-97) The useful plants of west tropical Africa, Vol 1 (1985 Families A-D), Vol 2 (1994 Families E-I), Vol 3 (1995 Families J-L), Vol 4 (1997, Families M-R). Royal Botanic Gardens, Kew

Buttle and Tuttle Ltd. (1996) World climate. Internet: URL: http:/ www.worldclimate.com, $(9.12 .1998)$

Connah G (1976) The Daima sequence and the prehistoric chronology of the Lake Chad region of Nigeria. J African Hist 17(3): $321-352$

Connah G (1981) Three thousand years in Africa: Man and his environment in the Lake Chad region of Nigera. Cambridge University Press, Cambridge

Dallwitz MJ, Paine TA, Zurcher EJ (1996) User's guide to the DELTA system. 4th edn, CSIRO Division of Entomology, Canberra

FWTA (1954-1972) Flora of West Tropical Africa, 2nd edn, Crown Agents for Oversea Governments and Administrations, London

Geel B van. Plicht J van der, Kilian MR, Klaver ER, Kouwenberg JHM, Renssen H, Reynaud-Ferrera I, Waterbolk HT (1998) The sharp rise of delta $14 \mathrm{C} \mathrm{ca} .800 \mathrm{cal}$ B.C.: possible causes, related climatic teleconnections and the impact on human environments. Radiocarbon 40(1): $535-550$

Grimm EC (1990) TILIA and TILIAGRAPH. PC spreadsheet and graphics software for pollen data. INQUA working group on data handling methods. Newsletter 4:5-7
Grondard A (1964) La végétation forestière au Tchad. Rev Bois For Trop 93: 15-34

Gronenborn D (1996) Kundiye - archaeology and ethnoarchaeology in the Kala-Balge area of Borno State, Nigeria. In: Pwiti G, Soper $R$ (eds) Aspects of African archacology. Papers from the 10th Congress of the PanAfrican Association for Prehistory and Related Studies. University of Zimbabwe Publications, Harare, pp 449-460

Gronenborn D (1998) Archaeological and ethnohistorical investigations along the southern fringes of Lake Chad, 1993-1996. African Arch Rev 15(4): 225-259

Gronenborn D, Neer W van, Skorupinski T (1995) Kleiner Vorbericht zur archäologischen Feldarbeit südlich des Tschad-Sees. Ber Sonderforschungsbereich 268, 5: 27-39

Gronenborn D, Wiesmüller B, Skorupinski T, Zach B (1996) Settlement history of the Kala-Balge region of Borno State, Nigeria. Ber Sonderforschungsbereichs 268, 8: 201-213

GTZ (1982) Die Ökologie und Bekämpfung des Blutschnabelwebervogels (Quelea quelea L.) in Nordostnigeria. Deutsche Gesellschaft für Technische Zusammenarbeit, Eschborn

Harlan JR (1971) Agricultural origins: centers and noncenters. Science 174: 468-474

Harlan JR (1989a) Wild-grass seed harvesting in the Sahara and SubSahara of Africa. In: Harris DR, Hillman GC (eds) Foraging and farming: the evolution of plant exploitation. Unwin Hyman, London, pp 79-98

Harlan JR (1989b) The tropical African cereals. In: Harris DR, Hillman GC (eds) Foraging and farming: the evolution of plant exploitation. Unwin Hyman, London, pp 335-343

Holmes J, Street-Perrott FA, Perrott RA, Stokes S. Waller MP, Huang Y, Eglinton G, Ivanovich M (1999) Holocene landscape evolution of the Manga Grasslands, NE Nigeria: evidence from palaeolimnology and dune chronology. J Geol Soc London 156: $357-368$

Houérou HN Le (1989) The grazing land ecosystems of the African Sahel. Ecological Studies 75. Springer, Berlin

IAWA Committee (1989) IAWA list of microscopic features for hardwood identification. IAWA Bull ns 10(3): 219-332

Irvine FR (1961) Woody plants of Ghana, Oxford University Press, Oxford

Jacomet S, Brombacher C, Dick M (1989) Archäobotanik am Zürichsee. Zürcher Denkmalpflege, Monographie 7

Jacques-Felix H (1971) Grain impressions. In: Munson PJ, The Tichitt Tradition: a late prehistoric occupation of the southwestern Sahara, appendix K: pp 355-361. PhD Dissertation, University Illinois, Urbana Champaign

Jonsson J (1998) Early plant economy in Zimbabwe. Studies in African Archaeology 16, Department of Archaeology and Ancient History, Uppsala University, Uppsala

Kahlheber S, Albert K-D, Höhn A (in press) A contribution to the palaeoenvironment of the archaeological site Oursi in north Burkina Faso. Ber Sonderforschungsbereichs 268

Keay RWJ (1959) An outline of Nigerian vegetation. Govt. Printer, Lagos

Kirscht H, Skorupinski T (1996) Soils and peasants - geographical and ethnological investigations on soil classification and land use in the southern Chad Basin. Ber Sonderforschungsbereichs 268, 8: 269-283

Klee M, Zach B (1999) Crops and wild cereals of three settlement mounds in NE-Nigeria - charred plant remains and impressions in ceramics from the last 4000 years. In: Veen $M$ van der (ed) Plants and people in Africa: recent archaeobotanical evidence. Plenum, New York, pp $81-88$

Leeuw PN de, Tuley P (1972) Vegetation. In: Aitchison PJ et al. (eds) The land resources of north east Nigeria, Vol 1, The environment. Land Resource Study 9. Surbiton, pp 121-155

Leeuw PN de, Lesslie A, Tuley P (1972) The land resources of North East Nigeria. Vol 4, Present and potential land use. Land Resource Study No. 9. Surbiton. 
Letouzey R (1968) Etude phytogéographique du Cameroun. In: Lechevalier P (ed) Encyclopédie biologique 69, Paris

Maydell HJ von (1983) Arbres et arbustes du Sahel. Leurs caractéristiques et leurs utilisations. Deutsche Gesellschaft für Technische Zusammenarbeit. Eschborn

McIntosh SK (1995) Excavations at Jenné-Jeno, Hambarketolo, and Kaniana(Inland Niger Delta, Mali). The 1981 Season. University of California Publications in Anthropology 20, Berkeley

Nachtigal, G. (1881) Sahara und Sudan. 2 vols. Berlin

Neumann K (1999a) Early plant food production in the West African Sahel - new evidence. In: Veen M van der(ed) Plants and people in Africa: recent archaeobotanical evidence. Plenum, New York, pp $73-80$

Neumann K (1999b) Charcoal from West African savanna sites questions of identification and interpretation. In: Veen $M$ van der (ed) Plants and people in Africa: recent archaeobotanical evidence. Plenum, New York, pp 205-220

Neumann K, Kahlheber S, Uebel D (1998) Remains of woody plants from Saouga, a medieval west African village. Veget Hist Archaeobot 7: 57-77

Neumann K. Schoch W, Détienne P, Schweingruber FH, with a contribution by HG Richter (2000) Woods of the Sahara and the Sahel - an anatomical atlas. Haupt, Bern

Pias J (1970) La végétation du Tchad (ses rapports avec les sols, variations paléobotaniques au Quaternaire). Trav Doc ORSTOM 6, Paris

Richter HG, Trockenbrodt M (1995) Computergestützte Holzartenbestimmung unter Einsatz des DELTA/INTKEY-Programmpakets. Holz als Roh- und Werkstoff 53: 215-219

Salzmann U (2000) Are savannas degraded forests? A Holocene pollen record from the Sudanian zone of NE Nigeria. Veget Hist Archaeobot 9: 1-15

Salzmann U, Waller M (1998) The Holocene vegetational history of the Nigerian Sahel based on multiple pollen profiles. Rev Palaeobot Palynol 100(1-2): 39-72

Servant M(1983) Séquences continentales et variations climatiques: évolution de Bassin du Tchad au Cénozoiques Supérieure. ORSTOM, Paris

Smith AB (1974) Preliminary report of excavations at Karkarichinkat Nord and Sud, Tilemsi Valley, Mali, spring 1972. West African $\mathrm{J}$ Arch 4: 33-55
Smith $A B$ (1972) A note on the flora and fauna from the postpalaeolithic sites of Karkarichinkat Nord and Sud. W African J Arch 5: 201-204

Sturm HJ, Franke I, Kirscht H, Ataholo M, Skorupinski T (1996) Natural environment and land use in the Chad Basin, NENigeria. Preliminary results of an interdiciplinary research. Ber Sonderforschungsbereichs 268, 8: 335-348

Thiemeyer H (1992) On the age of the Bama Ridge - A new $14 \mathrm{C}$ record from Konduga area, Borno State, NE-Nigeria. Z Geomorph NF 36(1): 113-118

Thiemeyer H (1993) A new 14C-record from the Bama Ridge near Konduga, Borno State, NE-Nigeria. Annals of Borno 8/9 (1991 1992): 239-242

Thiemeyer H (1997) Untersuchungen zur spätpleistozänen und holozänen Landschaftsentwicklung im südwestlichen Tschadbecken (NE-Nigeria). Jenaer Geographische Schriften 5, Friedrich Schiller Universität Jena.

Tschierschke K (1998) Statistische Analyse und Interpretation langjähriger Niederschlags- und Temperaturdaten von Klimastationen im Tschadseegebiet. Ber Sonderforschungsbereichs 268 , 10: $11-140$

Tubiana MJ, Tubiana J (1977) The Zaghawa from an ecological perspective. Balkema, Rotterdam

Vogelsang R, Albert K-D, Kahlheber S (2000) Le sable savant: Les cordons dunaires sahéliens au Burkina Faso comme archives archéologiques et paléoécologiques pour l'Holocène. Sahara 11: $51-68$

Wasylikowa K (1997) Flora of the 8000 years old archaeological site E-75-6 at Nabta Playa, Western Desert, southern Egypt. Acta Palaeobotanica 37(2), Kraków

White F (1983) The vegetation of Africa. A descriptive memoir to accompany the UNESCO/AETFAT/UNSO vegetation map of Africa. UNESCO, Paris

Willerding U (1991) Präsenz, Erhaltung und Repräsentation von Pflanzenresten in archäologischem Fundgut. In: Zeist W van, Wasylikowa K, Behre KE (eds) Progress in old world palaeoethnobotany. Balkema, Rotterdam, pp 25-51

Zach B, Kirscht H, Löhr D, Neumann K, Platte E (1996): Masakwa dry season cropping in the Chad Basin. Ber Sonderforschungsbereichs $268,8: 349-356$ 